\title{
Philosophy of Educational Research: New Epistemological, Methodological and Historical Approach
}

\author{
Omar A. Ponce a , Nellie Pagán-Maldonado a , \& José Gómez Galán ${ }^{\text {b }}$
}

Received: 10 September 2020 - Accepted: 19 November 2020

\begin{abstract}
The philosophy of educational research has traditionally been one of the least studied fields in the epistemology of the social sciences and humanities. However, a philosophical reflection on education itself, in the search for an ultimate explanation of what it means in the field of human evolution, necessarily implies knowing how to obtain information for its knowledge. This, in an epistemological context, implies analyzing the research methods used in the educational sciences. Throughout its history, educational research has experienced three stages of methodological evolution in its search for scientific effectiveness: (a) research without adhering to a particular model, (b) research applied to practice, and (c) research inserted into practice. The analysis of these methodological evolutions shows a history of great academic value, of fascinating philosophical debates, which every educator and educational researcher should know, and which nevertheless remains practically unexplored and unstudied in its entirety in the academic field.
\end{abstract}

Key-words: educational research; philosophy of education; epistemology; theory of education; methodology, history of education.

\section{Introduction}

There are many definitions of what educational research is (Hedges and Hanis-Martin, 2009; Condliffe and Shulman, 1999). The dominant position is to define it as "educational research. Educational research means investigating

\footnotetext{
${ }^{a}$ Ana G. Méndez University (Puerto Rico-United States), Cupey Campus ${ }^{\text {b }}$ Ana G. Méndez University (Puerto Rico-United States), Cupey Campus, \& University of Extremadura (Spain) (D) ORCID 0000-0002-9417-8824. Correspondence: Omar A. Ponce, Escuela de Educación, Universidad Ana G. Méndez (Recinto de Cupey) Avenida Ana G. Mendez, San Juan, 00926, Puerto Rico.um_oponce@uagm.edu
} 
educational practices, the effect of these practices on learning, and the study of educational problems (Johannigmeier \& Richardson, 2008; McMillan, \& Schumacher, 2005; Condliffe \& Schulman, 1999; Segovia, 1997; Charles, 1988; Cohen \& Manion, 1980). The interest in educational research emerges at the beginning of the 20th century, with the emergence of public education worldwide and the desire to develop it scientifically (Walters, 2009; Johannigmeier and Richardson, 2008; Condliffe, 2000). The argument at that time, and which is still valid, was that scientific research could improve public education as had happened in other professions. The term educational research emerges to refer to public education research (Johannigmeier \& Richardson, 2008; Shavelson \& Towne, 2002; Condliffe, 2000; Cohen \& Manion, 1980).

From its inception until the 1970 s, educational research was considered a field of multidisciplinary studies and a social science (Koichiro, 2013). The term, "multidisciplinary field of studies," was used to imply that education was a field where knowledge from the natural and social sciences was applied. Educational research until the 1970s was research in history, psychology, sociology, and philosophy (Condliffe, 2000; Johannigmeier and Richardson, 2008; Walters, 2009; Green, 2010; Koichiro, 2013). Since then, educational research is a science that is being discussed in a field of knowledge between the natural sciences and humanist philosophies (Gil Cantero and Reyero, 2014; Ponce, Pagán-Maldonado and Gómez Galán, 2017 and 2018). This paper reviews the methodological developments in educational research. The analysis shows three stages of maturity, with a history of philosophical debates of great academic value that every educator and educational researcher should know.

\section{Stage One: Educational research without a scientific research model}

The problems of public education during the last phase of the industrial revolution aroused the interest of some universities to contribute to the improvement of education. Two strategies emerge from this interest: (a) The creation of Colleges of Education in the universities, with teachers of the Natural Sciences (mathematics and biology), the Social Sciences (psychology) and the Humanities (Languages, History, Philosophy, Art, Music), to train future teachers who would work in the public schools, and (b) Researching education and solving its problems. This confronted the early scholars with the challenge of identifying the model to be used in educational research. At the beginning of the 20th century, the dominant model of scientific research in universities was the experimental method of the Natural Sciences. In the Social Sciences, the Humanities and Philosophy there were research practices with different names, very particular to their disciplines, not all of them considered scientific methods, which were permeating educational research. 
The academics in the first Colleges of Education in the universities did not develop a research model for education, but began their work with the research models of their respective academic disciplines (Condliffe, 2000; Johannigmeier and Richardson, 2008; Ponce, 2016).

Educational research began without a research model. The first and most controversial line of educational research was learning: what it is and how it happens. The first works came from philosophy, by the end of the 19th century. These works produced practical explanations about how learning occurred. The objective was that the classroom teacher had the tools to do his job effectively. In the United States, the first researchers of educational problems were physicians. They approached the study of education from a hygienic and child health perspective. Their approach used the doctor-patient model of medicine to examine what the teacher must know to educate his or her students. Psychologists used laboratory experiments to study student learning and mental processes. Sociologists developed field studies to understand the functioning of schools. Philosophers and humanists used the historical and philosophical study of society to propose statements to guide classroom practice.

By the 1900s, psychology, especially behaviorist psychology, as an "objective science" that studies mental functions and their structures, enjoyed greater acceptance than philosophical postulates in explaining learning problems. Laboratory experiments and quantification marked the scientific study of education in the topics of child development, human movement, hygiene and learning (Walters, 2009; Condliffe, 2000). Educational research at this time was a science of testing and statistical measurement of theories and attributes of learning, which resembled research in psychology (Walters, 2009). By the 1920s, it was evident that the term educational research encompassed many activities to study the problems of public education. In this decade it was evident that there were discrepancies among educational researchers about the scope of research methods, the academic disciplines studying education, and the need to define the type of science that is educational research (Johanningmeir \& Richardson, 2008).

\section{Second Stage: Research applied to practice}

In the 1920s, the Vienna Circle triggered the revolution in social research in European universities. Influenced by the experimental research model of the natural sciences, this group of academics from the University of Vienna pointed out the little validity that philosophy and the humanities had as "sciences" because they lacked a "method" that would allow them to verify the authenticity of the assertions they made about the social world. The Vienna Circle presented the philosophy of social research called empirical 
logic. It focused on the presence of a "scientific method" to corroborate any assertion of the authenticity of knowledge.

Experimental research was the most successful model in university scientific culture. Through this model, biology had a great impact on medicine, chemistry on agriculture and physics on engineering and technology. The findings of the natural sciences had several attractions for their applied professions, and that become aspirations in social research, their knowledge was generalizable and facilitated the prediction, control or prevention of situations. The first educational researchers adopted the experimental research model of the natural sciences. This implied the entry into the field of education of the research model applied to practice. This stage has four sub-stages; quantitative, qualitative, mixed, and science-based research for evidence-based professional practice:

\subsection{Quantitative education research.}

With the experimental method and the philosophy of empirical logic emerges the quantitative research model that became the scientific standard of educational research from 1930 to 1980, approximately. The quantitative research model focused on the following principles: (a) In the search for absolute truths, and the discovery of those universal laws of cause and effect that regulate learning. (b) In the application of a deductive model where the researcher tests theories, models or propositions and verifies them through experimentation. When experimentation is not possible, statistical tests of hypotheses are used to establish the validity of these or their probability of recurrence through surveys with random samples. (c) The use of standardized and objective measurement methods, procedures and instruments that exclude the values and biases of the researcher from the study. (d) Emphasis on verification of data collected. The presence of the scientific method is essential to evaluate the authenticity of the finding and the knowledge generated. (e) The accumulation of observable and verifiable facts as a mechanism to develop the knowledge to prevent, control or improve educational events or situations. Between 1950 and 1980, educational research relied exclusively on quantitative research to produce knowledge and develop the profession (Paul, 2005).

During these decades, educational research was characterized by the following: (a) research on the measurable and the observable, (b) objective research that excluded the subjective, the moral, and the political, and (c) research that produced the correct methods and practices of teaching and learning (e.g., Shadish, Cook, \& Campbell, 2002; O'Leary, 2004; Balnaves \& Caputi, 2001; Charles, 1988; Cohen \& Manion, 1980). 


\subsection{Qualitative education research.}

Between 1910 and 1930, many industrialized countries continue to experience the consequences of the change in life brought about by the industrial revolution. For example, the United States issued in 1918 the educational policy entitled the Cardinal Principles of Secondary Education that urged a redefinition of the curriculum in schools to respond to the country's social and economic needs. The study of the curriculum emerges as the cause and alternative to the problems of education. The curriculum, its construction, content, evaluation, and research and its relationship with society, emerges as the focus of education. The academic study of curriculum and instruction became the specialty that produced the first doctorates awarded in the Colleges of Education (Johanningmeir and Richardson, 2008; Condliffe, 2000).

Between 1930 and 1950, the study of the curriculum made it easier to connect disconnected pieces of this profession: (a) measurements of mental attributes developed by psychologists are aligned with specific curriculum activities and with teaching strategies developed by educators and philosophers. (b) Connecting and aligning the curricular sequence developed by educators with the stages of child growth developed by psychologists. (c) Connects attributes of the child's IQ and developmental levels, worked on by psychologists, with the curricular levels and their criteria for measuring learning, developed by educators. This brought up new variables in the learning equation: what role interpersonal relationships play in learning, what influence the student's culture has on learning, and how the learner's social class and mobility occur as a result of education. This established the intellectual ground for anthropologists to become interested in educational research (Johanningmeir \& Richardson, 2008; Condliffe, 2000).

In the 1940s, some anthropologists began to investigate the social and cultural phenomena of education with their field research methods. Entering schools to observe and interview to understand education in diverse educational settings was a departure from quantitative research methods. These methods are eventually known as qualitative research.

Between 1950 and 1970, qualitative research is evident in educational research. Phenomenology, hermeneutics, and symbolic interaction emerge as philosophies of qualitative research to address problems in education. The understanding of social dynamics, human behaviors, and learning from ethnography in social anthropology, phenomenology in philosophy, and case studies in education positioned qualitative methods as an alternative model of educational research.

Two reasons seem to explain the acceptance of qualitative research in education: (a) The first generations of doctors graduated from the Colleges of Education began to study learning from the perspective of teaching and the curriculum, thus moving away from the study of mental processes that 
swallowed the research in psychology. This new generation of educatorresearchers began to adopt concepts from philosophy and the humanities, such as constructivism, postmodernism and the theory of social criticism, to explain the social and political phenomena of education, which quantitative research did not provide. (b) The study of the curriculum and teaching caused interest in educational psychology, statistics and the construction of tests to measure learning to the point that these disciplines almost disappeared in some Schools of Education (Walters, 2009). Between the 1960s and 1980s, educational research distanced itself from the statistical measurement of educational phenomena, and from the search for universal laws that would explain learning (Codliffe, 2000). There is an emerging interest in researching education in its diverse contexts, such as urban and rural schools and with students from different socioeconomic levels, elementary and secondary levels, and by subjects of study such as mathematics, languages or physical education (e.g., Ponce, 2014b; Merriam, 2009; Lichtman, 2006; Woods, 1996; Bogdan and Biklen, 1992; Manen, 1990; Straus and Corbin, 1990).

\subsection{Research of mixed methods in education.}

Between the 1970s and 1980s, the contrast of views on educational research unleashed a strong controversy among proponents of educational research that produced causal and generalizable explanations of education (quantitative research) versus those who advocated research that allowed for the understanding of social and political phenomena in diverse educational contexts (qualitative research). The 1980s was characterized as the paradigm war because of the debate that developed in academic and political forums between the proponents of quantitative research and qualitative research (Eisner and Peshkin, 1990). The two axes of the controversy were the superiority of one research model over the other (Tashakkori and Teddlie, 1998), and the legitimacy of qualitative research in the field of education (Denzin, 2009).

The debate on paradigms generated much discussion that contributed to the development and sophistication of educational research. The paradigm war brought out the lack of consensus and the philosophical divisions that exist among educational researchers about the nature of knowledge, social reality, and methods of how to investigate education (Paul, 2005). A better understanding of the strengths, weaknesses, and fragility of the validity and limited generalizability of quantitative and qualitative research in education is emerging.

In the 1990s, mixed-method research emerged as a third model of educational research. During this decade, the need for a research methodology that would reconcile the precision of quantitative data with the descriptive richness of qualitative data became evident. Mixed-method research is positioned as a respected research model in education and as a real model for 
those who do not want to carry out quantitative or qualitative research (Caruth, 2013).

Several movements are emerging from the paradigm warfare that contributes to the development of mixed-method research in the field of education (Tashakkori and Teddlie, 1998; Greene, 2007; Ponce, 2011, 2014 and 2016): (a) A broader view of the concept of triangulation or the possibility of collecting data with more than one research strategy and approach, (b) The rejection of paradigmatic puritanism or strict adherence to quantitative or qualitative method philosophies, (c) A pragmatic vision of educational research or the emphasis on the research question and the product of study as the core of research emerges, (d) The compatibility thesis between quantitative and qualitative research has gained acceptance in the scientific research community of the United States and Europe. Quantitative and qualitative research, rather than different research approaches, are understood as complementary to each other (Phillips, D.C., 2009), and (e) the number of published studies employing mixed research methods is increasing.

The argument of these studies to integrate or combine quantitative and qualitative models in the design of their studies was the methodological robustness to study the problems of education (Ponce, 2014 and 2016; Caruth, 2013; Campos, 2009; Greene, 2007; Tashakkori and Teddlie, 1998). The emergence of mixed methods in educational research did not completely mitigate the paradigmatic debates among educational researchers about how to research education. Although mixed methods constitute a compromise between the objective elements of quantitative research and the subjective elements of qualitative research that were discussed in the paradigm war, the fact is that mixed-method research is a philosophical model of research applied to practice that does not enjoy the favor of some qualitative researchers (Flick, 2016).

\subsection{Science-based research and evidence-based professional practice.}

Between 1994 and 2001, the issue of the quality of public education was revived in political forums. On this occasion, the issue of the quality of educational research is linked to the quality of public education in the United States (Ponce, 2014 and 2016; Labarre, 2004; Condliffe, 2000), in England (Pring, 2000; Hammersley, 2007), and in Australia (Erickson, 2011). From the political point of view, it became clear that the expectation with educational research is that it provides the solutions to the problems of public education and that it prescribes its practices so that it develops scientifically. From the point of view of educational researchers, it became evident that the search for this ideal scientific method, and that it has been the driving force behind its development, has also been at the center of controversies with the quality of educational research (Condliffe and Shulman, 1999; Condliffe, 2000; Labaree, 2004; Walters, Lareau and Ranis, 2009). 
The paradigm debate in the 1980s was a philosophical debate rather than a methodological one. In 2002, the Federal Government of the United States politically ended the controversy by regulating educational research for federal funding (Shavelson and Towne, 2002). A similar situation occurred in England (Hammersley, 2007). The political action consisted of delegitimizing qualitative research by not considering it scientific research and imposing a science-based research model to provoke evidence-based education, as occurs in the field of medicine. Two controversies emerge with the political imposition of the science-based research model to provoke evidence-based professional practice: the logic that justifies such an imposition and the relevance of the science-based model to provoke evidence-based professional practice in the field of education.

Denzin (2009) uses the term of the second paradigm war and Barnhouse, Lareau and Ranis (2009) use the term "the political judgment of educational research" to refer to the action of the Federal Government. The second paradigm war was triggered by the publication of the National Research Council (2002) (Denzin, 2009). The NRC is a non-profit entity (Shevlson and Towne, 2002), funded by the Federal Government of the United States of America (Denzin, 2009). Its role is to recommend policies to resolve disputes in the research field (Shevlson and Towne, 2002). In its publication, Scientific Research in Education (2002), the NRC takes the following position on educational research: (a) The quality of educational research is questionable. There is no consensus on the criteria for defining the quality of educational research. (b) Educational research is fragmented, and not very connected to inform public policy or classroom practice. (c) There are too many philosophical and methodological differences among researchers about what educational research should look like. (d) The tendency in Colleges of Education to favor qualitative research, in some cases, at the expense of quantitative research, opened the door to criticism about the quality of educational research. (e) The distinction made by academia between quantitative and qualitative research, and the categorization of educational research as basic and applied, is erroneous. It argues that scientific research is the same in any discipline of study. To improve the quality of educational research, it recommends that all federally funded educational research be scientific so that teaching practice is evidence-based. He asserts that the political community wants to invest money to improve education safely.

It establishes the following criteria to consider a research as scientific: (a) The use of systematic and rigorous procedures that allow direct investigation of the research question. (b) That it recognizes the context of the research. (c) That it responds to conceptual frameworks that allow the study's relationship to research logic, data, and interpretation to be seen. (d) That it tests and corroborates hypotheses and theories. (e) It allows the data to be related to the method in such a way that the findings can be verified and are 
cumulative. (f) Rejects postmodernist schools of thought of social research that argue that knowledge is not objective. Although it recognizes that there are scientific designs of educational research, such as experiments with control groups in program evaluation, ethnographic studies, and case studies, not all educational research satisfies the criteria listed above. It recommends the implementation of guidelines and institutional compliance committees to evaluate, guarantee, and raise the quality of federally funded research.

Phillips (2009) and Vinovskis (2009) trace the influences of this political intervention to the paradigm wars of the 1980s. Walters (2009) points out that the debate on educational research since 1995 is not centered on the superiority of quantitative or qualitative methods, but on the quality, usefulness, and role of educational research in society: (a) It is questioned whether educational research is a reliable science or whether it really is a science. (b) It is questioned whether it is useful for the development of education, classroom practice, or the development of educational public policy. (c) Educational research is criticized for its lack of generalization and of defined theoretical frameworks to inform teaching practice. (d) It is criticized for its methodological ambivalence, the research questions it addresses, and the philosophical discrepancies it employs with the designs that guide it. The paradigm war of 1980 facilitated three movements that conclude in the "political judgment" that educational research faced (Walters, 2009): the movement of evidence-centered professional practice, the resurgence of the science-based research movement, and the political control of scientific research.

The second paradigm war was between educational researchers and educators against university academics from other disciplines, businessmen and politicians who criticize the quality of education and educational research. The criticism of these groups comes from the desire to improve public education, the clear economic interest they derive from federal funds, and their control of the field of scientific research. The 1980 paradigm debate, although academic, had political overtones that reflect the contrast between the values of the "scientific community" and the values of "influential groups" that lobby to defend the interests they represent (Lichtman, 2011; Denzin, 2009; Greene, 2007; Paul, 2005). The political presence in the field of education in the United States is historical and is evidenced through legislation and the allocation of federal funds for intervention and research programs (Condliffe, 2000). The political message to the academic community is an interest in a uniform vision of what "scientific research" in education means (National Research Council, 2002). The discussion of this second debate charted the path for the development of educational research aspiring to federal funds at this beginning of the 21 st century: quantitative and experimental methods, probability sample studies to produce science-based research, and evidence-based professional practice. An open position on 
science-based research and evidence-based professional practice is that it does not fully apply to the field of education. The field of education is nuanced by objective and subjective situations that involve multiple research approaches (Hammersley, 2007; Denzin, 2009).

\section{Third Stage: Research inserted in practice}

For the decade of 2010, the issue of the complexity of education is recurrent in educational research. The claim is that educational research needs a research model that helps it define itself as a unique field of scientific research, and that allows it to manage the phenomena that are manifested in this profession (Gómez Galán, 1998 and 2016; Clark, 2011; Cochran-Smith, Ell, Grudnoff, Ludlow, Haigh, and Hill, 2014; Gil Cantero and Reyero, 2014; McDonnell,2016; Ponce and Pagán-Maldonado, 2016; Gómez Galán and Sirignano, 2016; Ponce, Pagán-Maldonado and Gómez-Galán, 2017 and 2018; Ponce and Pagán-Maldonado, 2017; Ponce, Gómez Galán and PagánMaldonado, 2017) The issue is not whether research methods should be quantitative, qualitative, or mixed, as was the case in the 20th century, but rather to what extent the research model applied to practice captures the complexity of education to produce the valid and generalizable data needed in practice and in the development of educational policies (Mejías, 2008; Lee, 2010; Clark, 2011; Thompson, 2012; Gutiérrez and Penuel, 2014; Phillips, 2014; Rudolph, 2014; Snow, 2015; McDonnell,2016; Glass,2016; Ponce, Pagán-Maldonado and Gómez-Galán, 2017 and 2018).

The challenge of educational research in the 21 st century is that education is not a static research phenomenon, but is dynamic and responsive to the institutional context in which it occurs. In education, it is necessary to understand the students, who sometimes do not cooperate, sometimes are not interested, and sometimes do not even follow instructions. Classrooms are settings where multiple relationships and political and cultural influences are observed. The phenomena of education have little defined variables and are not constant. Education as a research phenomenon is very different from the physical phenomena studied in laboratories (Rudolph, 2014). Education is a domain where there is a great epistemological and methodological difficulty. Its practice is characterized by being liberating at times or by economic limitations at others, by government interference without warnings or with methodological impositions at times.

Educational research is difficult because learning is a phenomenon that involves people, in complex and specific contexts, that cannot be taken out of that context to be studied, where subjects have gender, sexual orientation, socioeconomic status, ethnicity, culture, interests and things that bore them, where some can eat breakfast and others cannot, some live in neighbourhoods where there are shootings and others do not (Phillips, 2014). This means that 
an educational phenomenon cannot be described in isolation from the other social factors around it that affect it in one way or another. Researching education involves dealing with the complicated, confusing, impure, and uncertain phenomena that are manifested in this profession. One cannot study education by looking only at its students with standardized tests. It is necessary to study students and their relationship with other students and components of education and society (Lingard, 2015). Educational research needs to take a more complex look at education, avoid simplification, and better understand the processes and contexts of education (Cochran-Smith, Ell, Grudnoff, Ludlow, Haigh, and Hill, 2014; Gil Cantero and Reyero, 2014; Ponce, Pagán-Maldonado and Gómez-Galán, 2017; Ponce and PagánMaldonado, 2017; Ponce, Gómez Galán and Pagán-Maldonado, 2017).

Educational research needs to be flexible, culturally sensitive, and evolutionary in order to track and understand how students and teachers adapt educational practices to the institutional realities they face (Gutiérrez \& Penuel, 2014). Progress in education will come from the use of multiple approaches that generate tools, such as curricula and programs, that serve the real needs of educators, and are supported by reliable information. This is possible if educational research adopts the model of "research embedded in practice" (Snow, 2015).

At the beginning of the 21 st century, the "Design Based Research" or an educational research methodology that tries to connect research with practice emerges. The objective is to increase the transfer of knowledge between research and educational practice. The following characteristics are present in the DBR and would allow producing an educational research embedded in practice to generate new knowledge and validate it simultaneously (Anderson and Shattuck, 2012): (a) To be placed in educational scenarios. Being in the educational context increases the validity of the knowledge that is generated at least in the context where the research is developed. (b) Focus on design to test an intervention. An effective strategy has to effectively migrate from the experimental classroom to the regular classroom, with the regular students and with the regular educators. Researchers and educators jointly design the instructional intervention with its theory and implementation sequence. (c) Mixed methods. Researchers have to be pragmatic in their approach to study all the dynamics that develop in the implementation of the intervention. This implies the use of several research methods in the same study. (e) Improvement in implementation. The intervention is improved in practice to obtain positive results. (f) Collaboration between researchers, educators, and students. Understanding the scope of the intervention involves the collaboration of all the actors to understand the multidimensionality of education. (g) Evolutionary design. Study design will evolve as the intervention progresses and develops to capture the dynamics that emerge. The study is modified as it goes along. (h) Practice in implementation. 
Procedural and implementation issues are eliminated because the researchers are embedded in the study. This should produce quantitative data without reference to margin of error because there are no probability samples. A detailed qualitative description of the processes and attitudes of the students and educators is produced, which allows the results to be appreciated.

The model of embedded research in practice seems to be most observed in the United States. It has yielded positive results in school improvement projects. It has been used in phases of years where researchers have intervened to study complete cycles of conceptualization, implementation, evaluation, and monitoring of interventions (Anderson and Shattuck, 2012). The research model embedded in practice responds to four gaps in educational research: (a) it generates knowledge of practice, (b) it validates new knowledge in practice, (c) it increases the generalization of knowledge about practice, and (d) it responds to the needs of the members and the realities of the educational systems (Ponce, Pagán-Maldonado and Gomez Galán, 2018).

\section{Conclusion}

Educational research is a maturing science. Its methodological evolution shows three phases of development: research without a particular research model, research applied to practice, and research inserted into practice. The analysis of these phases shows a history of academic philosophical debates that helps to better understand the field of education and educational research.

Systematizing the evolution of the philosophy of educational research can help to focus in a more efficient way which steps will be taken in the future. At present, when we are in a process of educational revolution produced by the presence of information and communication technologies (ICT) in society, the evolution of educational theory and practice in the new methodological molds that will be necessary in this new scenario must be taken into account.

\section{References}

Anderson, T., \& Shattuck, J. (2012). Design-Based Research: A Decade of Progress in Education Research? Educational Researcher, 41(1) 16-25. doi: $10.3102 / 0013189 X 11428813$

Balnaves, M., \& Caputi, P. (2001). Introduction to Quantitative Research Methods: An Investigative Approach. London, Thousand Oaks, and New Delhi: Sage Publications..

Barhouse, P., Lareau, A. y Ranis, S. H. (2009). Education Research on Trial: Policy Reform and the Call of Scientific Rigor. Routledge. New York, and London: Taylor and Francis Group. 
Bogdan, R., \& Biklen, S. (1992). Qualitative Research for Education: An Introduction to Theory and Methods ( $2^{\text {nd }}$ Ed). Boston, London, Toronto, Sydney, Tokyo, amd Singapore: Allyn and Bacon.

Campos, A. (2009). Métodos Mixtos de Investigación: Integración de la Investigación Cuantitativa y la Investigación Cualitativa. Bogotá: Investigar el Magisterio.

Caruth, G. D. (2013). Demystifying Mixed Methods Research Design: A Review of the Literature. Melvana International Journal of Education, 3(2), 112-122. doi: 10.13054/mije.13.35.3.2

Charles, C. M. (1988). Introduction to Educational Research. New York, and London: Longman.

Clark, C. (2011). Education(al) Research, Educational Policy-Making and Practice. Journal of Philosophy of Education, 45(1), 37-57. doi: 10.1111/j.1467-9752.2010.00769.x

Cochran, M., Ell, F., Grudnoff, L., Ludlow, L., Haigh, M., \& Hill. M. (2014). When Complexity Theory Meets Critical Realism: A Platform for Research on Initial Teacher Education. Teacher Education Quartely, 41(1), 105-122. doi: 10.4324/9781351201759-7

Cohen, L., \& Manion, L. (1980). Research Methods in Education (2nd Ed.). London, New York, and Sydney: Croom Helm.

Condliffe, E. (2000). An Elusive Science: The Troubling History of Education Research. Chicago, and London: The University of Chicago Press.

Condliffe, E., \& Shulman, L.S. (Ed) (1999). Issues in Education Research: Problems and Possibilities. San Francisco: National Academy of Education and Jossey-Bass Publishers.

Denzin, N. (2009). Qualitative Inquiry Under Fire: Toward a New Paradigm Dialogue. Walnut Creek, CA: Left Cost Press Inc.

Eisner, E., \& Peshking., A. (Eds.) (1990). Qualitative Inquiry in Education: The Continuing Debate. New York: Teachers College, Columbia University.

Erickson, F. (2005). A History of Qualitative Inquiry in Social and Educational Research. In N. K. Denzin, \& Y. S. Lincoln (eds.). The Sage Handbook of Qualitative Research (3rd ed., pp. 387-409). Los Angeles, and London: Sage.

Flick, U. (2016). Challenges for a New Critical Qualitative Inquiry: Introduction to the Special Issue. Qualitative Inquiry, 23(1), 3-7. doi: $10.1177 / 1077800416655829$

Gil-Cantero, F., \& Reyero, D. (2014). La Prioridad de la Filosofía de la Educación sobre las Disciplinas Empíricas de la Investigación Educativa. Revista Española de Pedagogía, 258, 263-280.

Glass, G. V. (2016). One Hundred Years of Research: Prudent Aspirations. Educational Researcher, 45(2), 69-72. doi: 10.3102/0013189X16639 026. 
Gómez Galán, J. (1998). Educational System Evaluation and Quality. Minneapolis, MN: College of Education and Human Development, University of Minnesota.

Gómez Galán, J. (Ed.). (2016). Educational Research in Higher Education: Methods and Experiences. Aalborg: River Publishers.

Gómez Galán, J., \& Sirignano, F. M. (2016). Theory and Practice in Educational Research. Naples: Università degli studi di Suor Orsola Benincasa.

Green, B. (2010). Knowledge, the Future, and Education(al) Research: A New-Millennial Challenge. The Australian Educational Researcher, 37(4), 43-62. doi: 10.1007/bf03216936

Greene, J. (2007). Mixed Methods in Social Inquiry. San Francisco: JosseyBass \& Wiley.

Gutiérrez, K. D., \& Penuel, W. R. (2014). Relevance to Practice as a Criterion for Rigor. Educational Researcher, 43(1), 19-23. doi: $10.3102 / 0013189 X 13520289$

Hammersley, M. (Ed) (2007). Educational Research and Evidence-Based Practice. Los Angeles, London, \& New Delhi: Sage Publications.

Hedges, L., \& Hanis-Martin, J. (2009). Can Non-Randomized Studies Provided Evidence of Causal Effects? A Case Study Using the Regression Discontinuity Design. In P. B. Walter, A. Lareau, \& S. H. Ranis (2009). Education Research on Trial: Policy Reform and the Call for Scientific Rigor (pp.105-113). New York, and Londres: Taylor \& Francis Group.

Johannigmeier, E. V., \& Richardson, T. (2008). Educational Research, the National Agenda, and Educational Reform: A History. Charlotte, NC: Age Publishing, Inc.

Koishiro, M. (2013). Cultivating the Ground for the Study of Education as an Inter-disciplinary Enterprise: A Philosophical Perspective. Educational Studies in Japan: International Yearbook, 7(3), 37-49. doi: 10.7571/esjkyoiku.7.37

Labaree, D (2004). The Trouble with Ed Schools. New Haven, and London: Yale University Press.

Lee, A. (2010). What Count as Educational Research? Spaces, Boundaries, and Alliances. The Australian Educational Researcher, 37(4) 63-78. doi: $10.1007 /$ bf03216937

Lichtman, M. (2006). Qualitative Research in Education: A User's Guide. Thounsand Oaks: Sage Publications.

Lichtman, M. (2011). Understanding and Evaluating Qualitative Educational Research. Los Angeles: Sage Publications.

Lingard, B. (2015). Thinking About Theory in Educational Research: Fieldwork in Philosophy. Educational Philosophy and Theory, 47(2), 173-191. doi: 10.1080/00131857.2013.793928 
Lysenko, L., Abrami, P., Bernand, R., Degenais, C., \& Janosz, M. (2014). Educational Research in Educational Practice: Predictors of Use. Canadian Journal of Education, 37(2), 1-26.

Manen, M. (1990). Researching Lived Experiences: Human Science for an Action Sensitive Pedagogy. Albany, NY: State University of New York Press.

McDonnell, L. M. (2016). Evolving Research Perspectives on Education Politics and Policy. Educational Researcher, 45(2), 142-148. doi: 10.3102/0013189X16639041.

McMillan, J. H., \& Schumacher, S., (2005). Investigación Educativa: Una Introducción Conceptual (5th Ed). Madrid: Pearson and Addison

Mejías, A. (2008). My self- as- philosopher and My self-as- Scientist Meet to do Research in the Classroom: Some Davidsonian Notes on the Philosophy of Educational Research. Studies in Philosophy and Education, 27(2-3), 161-171

Merriam, S. (2009). Qualitative Research: A Guide to Design and Implementation. New York: Jossey-Bass.

O'Leary, Z. (2004). The Essential Guide to Doing Research. London, Thousand Oaks, and New Delhi: Sage Publications.

Paul, J. (2005). Introduction to the Philosophies of Research and Criticism in Education and the Social Sciences. Upper Sanddle River, NJ: Pearson \& Merril Prentice Hall.

Peters, M. (2012). Editorial. Educational Research and the Philosophy of Context. Educational Philosophy and Theory, 44(8), 793-800. doi: 10.1111/j.1469-5812.2012.00845.x

Phillips, D.C. (2009). A Quixotic Quest? Philosophical Issues in Assessing the Quality of Educational Research. In P. Walters, A. Lareau y S. Ranis (Ed.). Education Research on Trial: Policy Reform and the Call for Scientific Rigor (pp. 785-907). New York, and London: Routledge.

Phillips, D. C. (2014). Research in the Hard Sciences, and in Very Hard "Softer" Domains. Educational Researcher, 43(1), 9-11. doi: 10.3102/0013189X13520293.

Ponce, O. A. (2011). Investigación de Métodos Mixtos en Educación: Filosofía y Metodología. Hato Rey: Publicaciones Puertorriqueñas Inc.

Ponce, O. A. (2014a) Investigación Cualitativa en Educación: Teoría, Prácticas y Debates. San Juan: Publicaciones Puertorriqueñas Inc.

Ponce, O. A. (2014b). Investigación de Métodos Mixtos en Educación. Hato Rey: Publicaciones Puertorriqueñas Inc.

Ponce, O. A., \& Pagán-Maldonado, N. (2015). Mixed Methods Research for Education: Capturing the Complexity of the Profession. International Journal of Educational Excellence, 1(1), 111-135. doi: 10.18562/ijee. 2015.0005 
Ponce, O. A., \& Pagán-Maldonado, N. (2016). Investigación Educativa: Retos y Oportunidades. In J. Gómez Galán, E. López Meneses y L. Molina (Eds.). Research Foundations of the Social Sciences (pp. 110-121). Cupey: UMET Press.

Ponce, O. A. (2016). Investigación Educativa. San Juan: Publicaciones Puertorriqueñas Inc.

Ponce, O. A., Pagán-Maldonado, N., \& Gómez Galán, J. (2017). Filosofía de la Investigación Educativa en una Era Global: Retos y Oportunidades de Efectividad Científica. San Juan: Publicaciones Puertorriqueñas, Inc.

Ponce, O. A., \& Pagán-Maldonado, N. (2017). Educational Research in the $21^{\text {st }}$ Century: Challenges and Opportunities for Scientific Effectiveness. International Journal of Educational Research and Innovation, 8, 2437.

Ponce, O. A, Gómez Galán, J., \& Pagán-Maldonado, N. (2017). Philosophy of Science and Educational Research. Strategies for Scientific Effectiveness and Improvement of the Education. European Journal of Science and Theology, 13(4), 35-46

Ponce, O. A. (2017). Investigación Educativa como un Movimiento Internacional: Nuevas Fronteras. International Journal of Educational Research and Innovation, 8, I-IV.

Ponce, O. A., Pagán-Maldonado, N., \& Gómez-Galán, J. (2018). Philosophy of Educational Research in a Global Era: Challenges and Oportunities for Scientific Effectiveness. San Juan: Publicaciones Puertorriqueñas, In.

Ponce, O. A., Gómez Galán, J., \& Pagán-Maldonado, N. (2018). Investigación-Evaluación en una Era de Rendición de Cuentas: Perspectiva Internacional. In E. López Meneses, D. Cobos, A. H. Martín, L. Molina, Alicia Jaén (eds.). Experiencias Pedagógicas e Innovación Educativa: Aportaciones desde la Praxis Docente e Investigadora (pp. 2628-2642). Barcelona: Editorial Octaedro.

Prings, R. (2000). Philosophy of Educational Research ( $2^{\text {nd }}$ Ed). London: Continum.

Radford. M (2006). Researching Classrooms: Complexity and Chaos. British Educational Research Journal, 32(2), 177-190. doi: 10.1080/014119206 00568950

Rudolph, J. L. (2014). Why Understanding Science Matters: The IES Research Guidelines as a Case in Point. Educational Researcher, 43(1), 15-18. doi: 10.3102/0013189X13520292

Segovia, J. (1997). Investigación Educativa y Formación del Profesorado. Madrid: Editorial Escuela Española.

Shadish, W., Cook, T., \& Campell, D. (2002). Experimental and QuasiExperimental Designs for Generalized Causal Inferences. Boston \& New York: Houghton Mifflin Company. 
Shavelson, R., \& Towne, L. (Ed) (2002). Scientific Research in Education. Washington, DC.: National Research Council. National Academy Press. Snow, C. E. (2015). Rigor and Realism: Doing Educational Science in the Real World. Educational Researcher, 44(9), 460-466. doi: 10.3102/ $0013189 X 15619166$.

Strauss, A., \& Corbin, J. (1990). Basics of Qualitative Research: Grounded Theory Procedures and Techniques. Newbury Park, London, and New Delhi: Sage Publications.

Tashkkori, A., \& Teddlie, C. (1998). Mixed Methodology: Combining Qualitative and Quantitative Approches. Thounsand Oaks: Sage Publications.

Thompson, C. (2012). Theorizing Education and Educational Research. Studies in Philosophy and Education, 31(3), 239-250. doi: 10.1007/s11217-012-9290-y

Vinovkis, M. (2009). A History of Efforts to Improve the Quality of Federal Educational Research: From Gardner's Task Force to the Institute of Educational Science. In P. Walter, A. Lareau \& S. H. Ranis (Eds). Education Research on Trial: Policy Reform and the Call for Scientific Rigor (pp. 51-80). New York, and London: Taylor \& Francis Group.

Walters, P. B. (2009). The Politics of Knowledge. In P. Walter, A. Lareau \& S. H. Ranis (Eds). Education Research on Trial: Policy Reform and the Call for Scientific Rigor (pp. 744-776). New York, and London: Taylor $\&$ Francis Group.

Walter, P. B., Lareau, A., \& Ranis, S. H. (2009). Education Research on Trial: Policy Reform and the Call for Scientific Rigor. New York, and London: Taylor \& Francis Group.

Woods, P. (1996). Researching the Art of Teaching. Ethnography for Educational Use. London, and New York: Routledge. 